\title{
PEMBUATAN DAN KARAKTERISASI ARANG AKTIF DARI BATANG TANAMAN GUMITIR (TAGETES ERECTA) DENGAN AKTIVATOR NaOH
}

\author{
Emmy Sahara*, Ni Kadek Dahliani dan Ida Bagus Putra Manuaba
}

Progam Studi Kimia FMIPA Universitas Udayana, Bukit Jimbaran, Badung, Bali 80361

*Email: emmy_sahara@unud.ac.id

\begin{abstract}
ABSTRAK
Dalam penelitian ini dilakukan pembuatan dan karakterisasi arang aktif dari batang tanaman gumitir (Tagetes erecta) menggunakan aktivator $\mathrm{NaOH}$. Penelitian ini bertujuan untuk membuat arang aktif dan menentukan konsentrasi $\mathrm{NaOH}$ optimum yang dibutuhkan untuk mendapatkan arang aktif dengan karakteristik yang baik ditinjau dari kadar air, kadar zat mudah menguap, kadar abu total, kadar karbon, daya serap terhadap metilen biru, dan daya serap terhadap iod. Hasil penelitian menunjukkan bahwa arang aktif yang diaktivasi dengan natrium hidroksida $(\mathrm{NaOH})$ 2,5\% menghasilkan arang aktif dengan karakteristik terbaik dan memenuhi standar baku mutu SNI 06 - 3730 - 1995 tentang arang aktif teknis. Arang aktif yang diperoleh dalam penelitian ini memiliki kadar air sebesar 1,25 $\pm 0,02 \%$, kadar zat mudah menguap sebesar $12,00 \pm 0 \%$, kadar abu total sebesar 5,33 $\pm 0,41 \%$, kadar karbon sebesar $81,41 \%$, daya serap terhadap metilen biru sebesar $199,97 \pm 0,07 \mathrm{mg} / \mathrm{g}$, dan daya serap terhadap $\mathrm{I}_{2}$ sebesar $728,09 \pm 2,16 \mathrm{mg} / \mathrm{g}$. Hasil analisis dengan spektrofotometer FTIR menunjukkan bahwa arang aktif tersebut mempunyai gugus fungsi $\mathrm{C}-\mathrm{H}$ alifatik, $\mathrm{C}=\mathrm{O}, \mathrm{C}=\mathrm{C}$ aromatik, dan $\mathrm{O}-\mathrm{H}$ ikatan hidrogen.
\end{abstract}

Kata Kunci: $\quad$ arang aktif, karakterisasi, natrium hidroksida, tanamam gumitir

\section{ABSTRACT}

This research investigated the manufacture and characterization of activated carbon from stem of marigold plant (Tagetes erecta) using $\mathrm{NaOH}$ as the chemical activator. The aim of this research was to make activated carbon and determine the optimum concentration of $\mathrm{NaOH}$ required for activating the carbon in order to obtain activated carbon with good characteristics, in terms of the levels of water, volatile substance, total ash, carbon, as well as the adsorptions of methylene blue and iodine.The result of this research showed that the activated carbon resulted in with the use of $2.5 \% \mathrm{NaOH}$ gave the best characteristics that fulfilled the standard quality of SNI 06-3730-1995 about technical activated carbon, which were as follows: water level of $1.25 \pm 0.02 \%$, volatile substance level of $12.00 \pm 0 \%$, total ash level of $5.33 \pm 0.41 \%$, carbon level of $81.41 \%$, methylene blue absorption of $199.97 \pm 0,07 \mathrm{mg} / \mathrm{g}$, and iodine absorption of $728.09 \pm 2.16 \mathrm{mg} / \mathrm{g}$. The FT-IR spectrum showed that the activated carbon contained some functional groups of $\mathrm{C}-\mathrm{H}$ aliphatic, $\mathrm{C}=\mathrm{O}, \mathrm{C}=\mathrm{C}$ aromatic, and $\mathrm{O}-\mathrm{H}$ from hydrogen bonding.

Keywords: $\quad$ activated carbon, characterization, marigold plant, sodium hydroxide

\section{PENDAHULUAN}

Di Indonesia, khususnya di Bali tanaman gumitir dibudidayakan dengan sangat luas. Tanaman gumitir adalah salah satu tanaman yang memiliki banyak kegunaan dimana bagian tanaman gumitir yang biasanya dimanfaatkan oleh masyarakat adalah bagian bunga dan daunnya karena berkhasiat sebagai bahan pembuatan obat (Vasudevan et al., 1997), sedangkan bagian batangnya sangat jarang digunakan oleh masyarakat. Salah satu pemanfaatan biomassa seperti halnya batang gumitir ini adalah dapat dimanfaatkan sebagai bahan untuk pembuatan arang aktif karena tanaman gumitir yang tumbuh di daerah dengan suhu $20^{\circ} \mathrm{C}-30^{\circ} \mathrm{C}$ memiliki kandungan karbon lebih dari $40 \%$ (Lersel, 2006). Arang merupakan produk dari proses karbonisasi kayu yang sebagian besar komponennya merupakan karbon, sedangkan arang aktif merupakan arang yang telah mengalami pemrosesan lebih lanjut dengan pemanasan tinggi atau dengan menggunakan bahan-bahan kimia, sehingga 
pori-pori yang dimiliki arang menjadi terbuka dan mampu menjadi adsorben (Marsh and Reinoso, 2006).

Karbonisasi batang gumitir pada suhu $300^{\circ} \mathrm{C}$ selama 90 menit (Siaka, 2016) dan aktivasi dengan $\mathrm{H}_{3} \mathrm{PO}_{4} 15 \%$ (Sahara, 2017) telah dilaporkan menghasilkan arang aktif dengan karakteristik yang memenuhi baku mutu menurut SNI 06 - 3730 - 1995 tentang arang aktif teknis. Penambahan asam fosfat dapat dilakukan pada saat karbonisasi (Qin et al., 2014) maupun setelah arang terbentuk (Sahara, 2017).

Arang aktif memiliki banyak manfaat, yaitu sebagai pembersih air, pemurnian gas, industri gula, pengolahan limbah cair dan sebagainya. Dalam dunia industri, arang aktif sangat diperlukan karena dapat mengabsorbsi bau, warna, gas, dan logam. Bahan baku yang dapat dibuat menjadi arang aktif adalah semua bahan yang mengandung karbon, yang berasal dari tumbuh-tumbuhan, binatang mapun barang tambang. Bahan tersebut merupakan berbagai jenis kayu, sekam padi, tulang binatang, batubara, tempurung kelapa, kulit biji kopi (Cooney, 1980).

Pembuatan arang aktif dilakukan melalui proses karbonisasi yang dilanjutkan dengan proses aktivasi. Untuk membuat arang aktif dari bahan dasar organik terdapat dua metode yang dapat digunakan, yaitu metode aktivasi fisik (physical activation) dan metode aktivasi kimiawi (chemical activation). Pemilihan jenis aktivator akan berpengaruh terhadap kualitas arang aktif. Masing-masing jenis aktivator akan memberikan efek atau pengaruh yang berbedabeda terhadap luas permukaan maupun volume pori- pori arang aktif yang dihasilkan. Bahan kimia yang dapat digunakan sebagai aktivator adalah asam, basa maupun garam diantaranya adalah $\mathrm{H}_{3} \mathrm{PO}_{4}, \mathrm{NaOH}, \mathrm{ZnCl}_{2}$ (Marsh dan Reinoso, 2006).

\section{MATERI DAN METODE}

\section{Bahan}

Bahan-bahan yang digunakan dalam penelitian ini meliputi sampel limbah batang tanaman gumitir yang diperoleh dari "Perkebunan Bali Gumitir" di daerah Mayungan, Baturiti-Tabanan. Bahan kimia yang digunakan meliputi: $\mathrm{I}_{2}, \mathrm{Na}_{2} \mathrm{~S}_{2} \mathrm{O}_{3} .5 \mathrm{H}_{2} \mathrm{O}$,
$\mathrm{KI}, 1_{2}, \mathrm{~K}_{2} \mathrm{Cr}_{2} \mathrm{O}_{7}, \mathrm{NaOH}$, metilen biru, amilum, dan aquades. Semua bahan kimia yang digunakan mempunyai kemurnian proanalisis.

\section{Peralatan}

Alat yang digunakan meliputi alat-alat gelas, ayakan $106 \mu \mathrm{m}$ dan $212 \mu \mathrm{m}$, cawan porselin, kertas saring Whatman no. 12, kaca arloji, pipet volume, pipet mikro, bola hisap, buret, labu erlenmeyer, timbangan analitik, pengaduk magnet, batang pengaduk, mortar, botol semprot, oven, tanur, desikator, dan $\mathrm{pH}$ meter. Peralatan instrumen yang digunakan adalah spektrofotometer Shimadzu IR Prestige21, dan Shimadzu UV-1800di laboratorium bersama FMIPA Universitas Udayana.

\section{CARA KERJA}

\section{Penyiapan Bahan}

Sampel batang tanaman gumitir dicuci dengan air kran, lalu dibilas dengan aquades. Kemudian sampel dipotong kecil- kecil dan dikeringkan dalam oven pada suhu $105{ }^{\circ} \mathrm{C}$ hingga diperoleh massa konstan.

\section{Karbonisasi Batang Gumitir Menjadi Arang}

Sebanyak 500 gram sampel kering dikarbonisasi dalam tanur pada suhu $300^{\circ} \mathrm{C}$ selama 90 menit. Setelah dingin, arang yang terbentuk ditimbang kemudian ditentukan persen rendemennya. Selanjutnya, arang digerus lalu diayak dengan ukuran ayakan 106 $\mu \mathrm{m}$ dan $212 \mu \mathrm{m}$, sehingga didapatkan partikel arang dengan ukuran di antara $212 \mu \mathrm{m}-106 \mu \mathrm{m}$.

\section{Aktivasi Arang}

Ke dalam 5 buah gelas beaker dimasukkan masing-masing $8 \mathrm{~g}$ arang hasil pirolisis. Lalu ditambahkan sebanyak $100 \mathrm{~mL}$ $\mathrm{NaOH}$ dengan konsentrasi $0,5 \%, 1,0 \%, 1,5 \%$, $2,0 \%$, dan 2,5\%. Campuran kemudian didiamkan selama 24 jam lalu disaring dan dibilas dengan aquades hingga didapatkan $\mathrm{pH}$ netral. Arang kemudian dipanaskan di dalam oven suhu $105^{\circ} \mathrm{C}$ selama 30 menit hingga kering. Arang aktif yang terbentuk kemudian didinginkan hingga mencapai suhu ruangan dan ditimbang. Proses aktivasi dilakukan sebanyak 3 kali dan ditentukan \% rendemennya. 


\section{Karakterisasi Arang Aktif}

Prosedur analisis arang aktif mengacu pada Standar Nasional Indonesia 06 - 3730 - 1995 tentang arang aktif teknis.

\section{a. Kadar air}

Satu gram arang aktif ditempatkan dalam gelas arloji yang telah diketahui massanya lalu dikeringkan dalam oven pada suhu $105{ }^{0} \mathrm{C}$ hingga diperoleh massa konstan, kemudian didinginkan dalam desikator, selanjutnya ditimbang.

\section{b. Kadar zat mudah menguap}

Satu gram arang aktif dipanaskan dalam tanur pada suhu $900{ }^{\circ} \mathrm{C}$ selama 15 menit, kemudian didinginkan dalam desikator dan selanjutnya ditimbang.

\section{c. Kadar abu total}

Satu gram arang aktif ditempatkan di dalam cawan porselin, lalu dipanaskan dalam oven pada suhu $105{ }^{\circ} \mathrm{C}$ sampai diperoleh massa konstan. Sampel dalam cawan kemudian dimasukkan ke dalam tanur dan selanjutnya diabukan pada suhu $650{ }^{\circ} \mathrm{C}$ selama 4 jam, lalu didinginkan dalam desikator. Abu yang terbentuk ditimbang

\section{d. Kadar karbon terikat}

Kadar karbon terikat dalam arang aktif adalah hasil dari proses pengarangan selain abu, air dan zat-zat yang mudah menguap.

\section{e. Daya serap terhadap iod}

Satu gram arang aktif dimasukkan ke dalam labu erlenmeyer, kemudian ditambahkan $25 \mathrm{~mL}$ larutan iodium 0,1 N. Larutan diaduk selama 15 menit lalu erlenmeyer ditutup dan disimpan di tempat yang gelap selama 2 jam. Larutan kemudian disaring, lalu filtratnya dipipet 10 $\mathrm{mL}$, dimasukkan ke dalam labu erlenmeyer yang bersih dan dititrasi dengan larutan $\mathrm{Na}_{2} \mathrm{~S}_{2} \mathrm{O}_{3} 0,1 \mathrm{~N}$ hingga larutan berwarna kuning muda. Sebanyak $1 \mathrm{~mL}$ indikator amilum $1 \%$ ditambahkan pada filtrat dan titrasi dilanjutkan sampai warna biru tepat hilang. Volume larutan $\mathrm{Na}_{2} \mathrm{~S}_{2} \mathrm{O}_{3}$ yang digunakan dicatat dan dihitung daya serap arang aktif terhadap iodin dalam $\mathrm{mg} / \mathrm{g}$.

\section{f. Daya serap terhadap metilen biru}

Dibuat kurva kalibrasi larutan metilen biru dengan konsentrasi 0, 1, 2, 3, 4 dan $5 \mathrm{mg} / \mathrm{L}$. Kurva digunakan untuk menentukan konsentrasi metilen biru sisa sehingga metilen biru yang diserap oleh arang aktif dapat diketahui.

Satu gram arang aktif dimasukkan ke dalam gelas beaker dan ditambahkan $100 \mathrm{~mL}$ larutan metilen biru $2.000 \mathrm{mg} / \mathrm{L}$, diaduk dengan pengaduk magnetik selama 30 menit. Larutan kemudian disaring dengan kertas saring Whatman no. 12, absorbansi dari filtratnya diukur dengan spektrofotometer UV-Vis pada $\lambda_{\max }$ metilen biru.

\section{g. Gugus fungsi}

Arang aktif yang menunjukkan karakter terbaik dianalisis spektra infra merahnya sehingga dapat diketahui gugus-gugus fungsinya.

\section{HASIL DAN PEMBAHASAN}

\section{Karakterisasi Arang Aktif}

Untuk mengetahui mutu arang aktif yang dihasilkan, maka hasil karakterisasi dalam penelitian ini dibandingkan dengan karakterisasi arang menurut SNI 06 - 3730 1995 tentang arang aktif teknis.

\section{a. Kadar air}

Penentuan kadar air bertujuan untuk mengetahui sifat higroskopis dari arang aktif yang dihasilkan, dimana arang aktif mempunyai sifat salinitas yang besar terhadap air. Gambar 1 menunjukkan bahwa arang yang diaktivasi dengan natrium hidroksida 0,5\% memiliki kadar air yang paling rendah yaitu $1,25 \pm 0,02 \%$, sedangkan pada konsentrasi $\mathrm{NaOH} 1,5 \%$ memiliki kada air yang paling tinggi. Hasil penentuan kadar air yang disajikan pada Gambar 1 menunjukkan bahwa arang aktif yang dibuat dengan berbagai konsentrasi natrium hidroksida dalam penelitian ini memenuhi baku mutu kadar air untuk arang aktif (maks. 15\%).

\section{b. Kadar zat mudah menguap}

Hasil penentuan kadar zat mudah menguap arang aktif dari batang gumitir dapat dilihat pada Gambar 2.

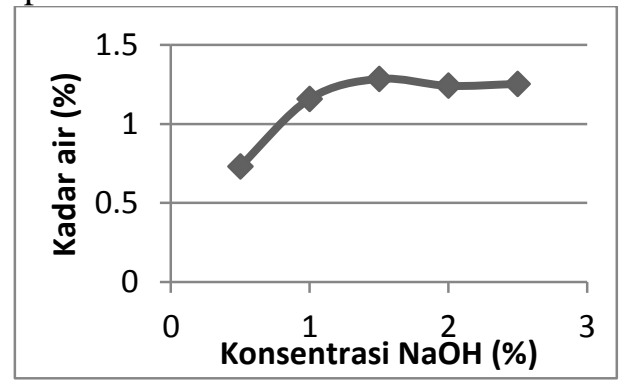

Gambar 1. Hubungan antara Konsentrasi Natrium Hidroksida dan Kadar Air Arang Aktif 


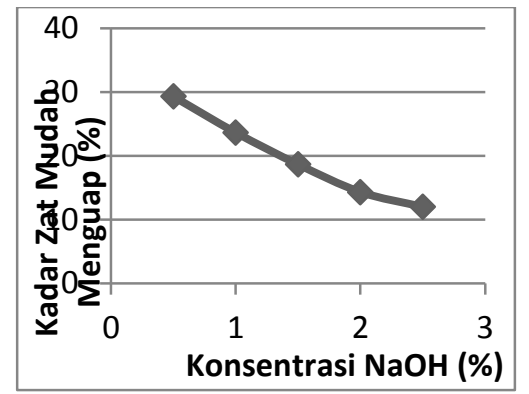

Gambar 2. Hubungan antara Konsentrasi $\mathrm{NaOH}$ dan Kadar Zat Mudah Menguap Arang Aktif

Dari gambar di atas dapat dilihat perbandingan kadar zat mudah menguap arang aktif pada berbagai konsentrasi aktivator natrium hidroksida, yaitu, arang aktif yang diaktivasi dengan natrium hidroksida pada konsentrasi 2,5\% memiliki kadar zat mudah menguap yang paling rendah yaitu $12 \%$, sedangkan arang yang diaktivasi menggunakan natrium hidroksida $0,5 \%$ memiliki kadar zat mudah menguap yang paling tinggi. Hasil penentuan kadar zat mudah menguap menunjukkan bahwa arang aktif yang dibuat dengan berbagai konsentrasi natrium hidroksida dalam penelitian ini memenuhi baku mutu kadar zat mudah menguap arang aktif teknis yaitu maksimal sebesar $25 \%$.

\section{c. Kadar Abu Total}

Kadar abu pada arang aktif ditentukan untuk mengetahui kandungan oksida logam dalam arang aktif. Kadar abu arang aktif merupakan sisa yang tertinggal pada saat arang dibakar (Pari, 2009). Berdasarkan SNI arang aktif dalam bentuk serbuk yang baik memiliki kadar abu total maksimal sebesar $10 \%$.

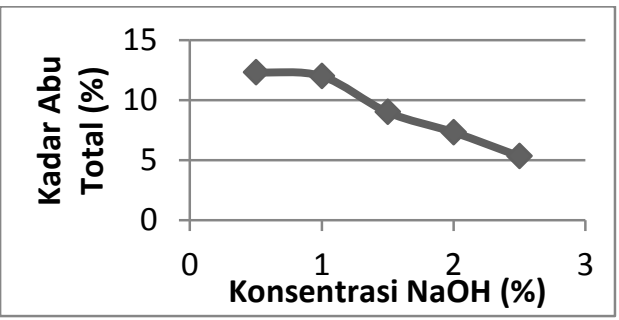

Gambar 3. Hubungan antara Konsentrasi $\mathrm{NaOH}$ dan Kadar Abu Total Arang Aktif
Menurut SNI 06 - 3730 - 1995 tentang arang aktif teknis, kadar abu total maksimum arang aktif adalah 10\%. Dari Gambar 3 dapat dilihat bahwa arang yang diaktivasi dengan natrium hidroksida 2,5\% memiliki kadar abu total yang paling rendah yaitu 5,33\%. sedangkan arang yang diaktivasi menggunakan natrium hidroksida $0,5 \%$ memiliki kadar abu total paling tinggi.

\section{d. Kadar karbon}

Karbon merupakan jumlah karbon murni yang terkandung di dalam arang. Suhu pada proses karbonisasi sangat berpengaruh terhadap kualitas arang tersebut, termasuk kadar karbon. Kadar karbon ditentukan untuk mengetahui kandungan karbon setelah proses karbonisasi dan aktivasi. Besar kecilnya kadar karbon terikat pada karbon aktif dipengaruhi oleh variasi kadar air, abu dan zat mudah menguap.

Berdasarkan grafik pada Gambar 4 dapat dilihat bahwa arang yang diaktivasi dengan natrium hidroksida 2,5\% memiliki kadar karbon yang paling tinggi yaitu $81,41 \%$ (minimal 65), sedangkan arang yang diaktivasi menggunakan natrium hidroksida 0,5\% memiliki kadar karbon paling rendah. Semakin besar konsentrasi maka kadar karbon yang diperoleh semakin meningkat. Hal ini disebabkan karena konsentrasi bahan kimia yang ditambahkan dalam aktivasi dapat memperlambat laju reaksi pada proses oksidasi sehingga meningkatkan kadar karbon.

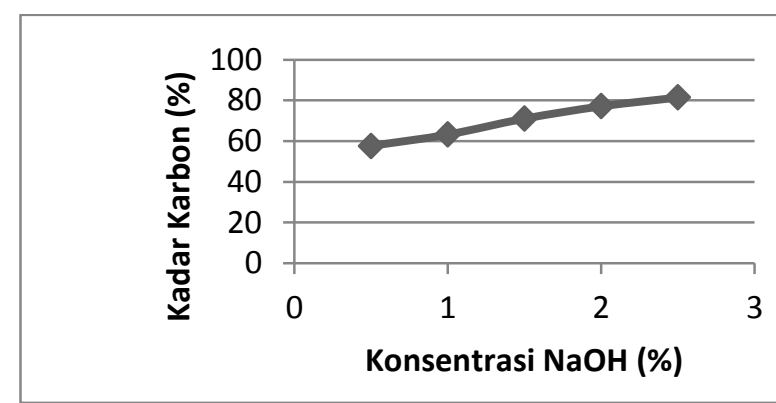

Gambar 4. Hubungan antara Konsentrasi $\mathrm{NaOH}$ dan Kadar Karbon Arang Aktif 
Menurut SNI arang aktif dalam bentuk serbuk yang baik memiliki kadar karbon minimum sebesar $65 \%$. Berdasarkan hal tersebut, kadar karbon yang terkandung dalam arang aktif yang dibuat dengan berbagai konsentrasi aktivator natrium hidroksida dalam penelitian ini telah memenuhi baku mutu kadar karbon arang aktif.

e. Daya serap terhadap metilen biru

Penentuan daya serap metilen biru bertujuan untuk mengetahui luas permukaan arang aktif serta kemampuannya dalam menyerap larutan berwarna (Jankowska et al., 1991). Kapasitas penyerapan metilen biru merupakan salah satu karakteristik yang harus dimiliki oleh suatu produk arang aktif. Daya serap terhadap senyawa ini memiliki kemampuan adsorpsi karbon terhadap senyawa - senyawa organik. Menurut SNI 06 - 3730 1995 tentang arang aktif teknis daya serap terhadap metilen biru minimal adalah 120 $\mathrm{mg} / \mathrm{g}$. Arang aktif yang diaktivasi dengan natrium hidroksida 2,5\% memiliki daya serap metilen biru yang paling tinggi yaitu sebesar $199,9672 \mathrm{mg} / \mathrm{g}$, sedangkan arang yang diaktivasi menggunakan natrium hidroksida $0,5 \%$ memiliki daya serap metilen biru paling rendah yaitu sebesar 199,9393 mg/g. Hasil penentuan daya serap metilen biru dari arang aktif selengkapnya dapat dilihat pada Gambar 5.

f. . Daya serap iodin

Daya serap terhadap iodin ditentukan dengan tujuan mengetahui kemampuan adsorpsi dari adsorben yang dihasilkan terhadap larutan berbau. Daya serap iodin diperoleh dari analisis filtrat campuran iodin dan arang aktif. Analisis dilakukan dengan

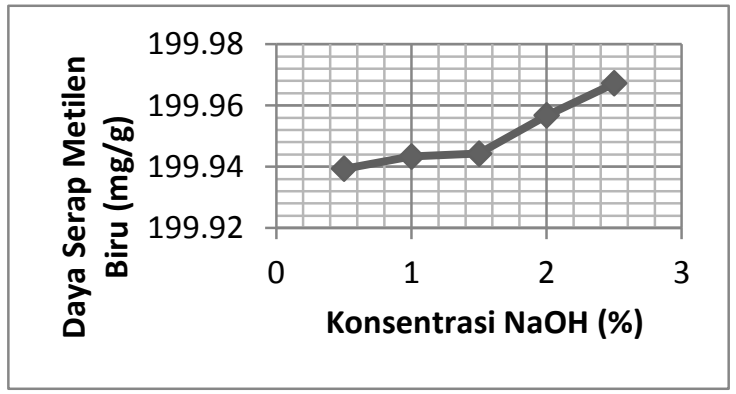

Gambar 5. Hubungan antara Konsentrasi $\mathrm{NaOH}$ dan Daya Serap Terhadap Metilen Biru titrasi iodometri lalu dihitung daya serap arang aktif terhadap larutan iodin dalam mg/gram.

Arang yang diaktivasi dengan natrium hidroksida 2,5\% memiliki daya serap iodin yang paling tinggi yaitu $728,09 \mathrm{mg} / \mathrm{g}$, sedangkan arang yang diaktivasi menggunakan natrium hidroksida 2,0\% memiliki daya serap iodin paling rendah. Hasil karakterisasi daya serap iodin selengkapnya disajikan pada Gambar 6.

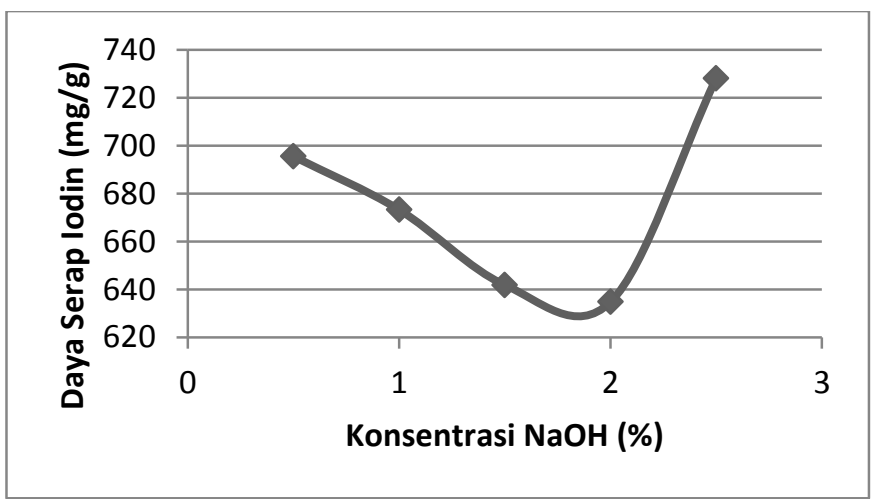

Gambar 6. Hubungan antara Konsentrasi $\mathrm{NaOH}$ dan Daya Serap Arang Aktif terhadap Iodin

g. Gugus fungsi

Dari semua data hasil karakterisasi, arang aktif yang diaktivasi dengan natrium hidroksida pada konsentrasi 2,5\% menunjukkan karakteristik yang paling baik, sehingga arang aktif ini selanjutnya dianalisis gugus fungsinya menggunakan spektrofotometer inframerah. Analisis FTIR digunakan untuk melihat adanya serapan-serapan karakteristik dan karbon aktif yang dihasilkan, sehingga dapat diprediksi jenis gugus fungsi yang terdapat pada karbon aktif.

Hasil identifikasi gugus fungsi arang dari batang gumitir dengan spektrofoto-meter inframerah menunjukkan bahwa arang yang tidak diaktivasi mengandung gugus fungsi $\mathrm{O}-$ $\mathrm{H}$, dan C-H alifatik, dimana serapan karakteristiknya melebar pada bilangan gelombang $3373,50 \mathrm{~cm}^{-1}$ (gugus $\mathrm{O}-\mathrm{H}$ asam), $2960,73 \mathrm{~cm}^{-1}$ dan $2931 \mathrm{~cm}^{-1}$ (C-H alifatik), yang diperkuat dengan munculnya serapan pada daerah 1379, $10 \mathrm{~cm}^{-1}$ (Siaka, 2017).

Hasil analisis spektra inframerah arang yang diaktivasi dengan natrium hidroksida konsentrasi 2,5\% adalah sebagai Gambar 7 . 


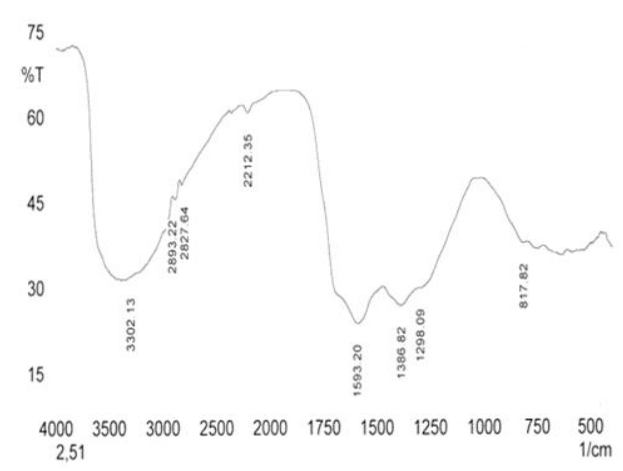

Gambar 7. Spektra Inframerah Arang Aktif

Karbonisasi batang gumitir pada suhu $300^{\circ} \mathrm{C}$ selama 90 menit dan aktivasi dengan $\mathrm{NaOH}$ menghasilkan arang aktif yang menunjukkan masih adanya senyawa- senyawa organik. Dari spektra yang ditunjukkan pada Gambar 7 dapat dilihat bahwa arang aktif yang yang diaktivasi dengan natrium hidroksida memiliki serapan - serapan karakteristik pada bilangan gelombang: $817,82 \mathrm{~cm}^{-1}(\mathrm{C}-\mathrm{H}$ bending luar bidang aromatik), 1298,09 $\mathrm{cm}^{-1}$ (metilene alifatik atau $\mathrm{C}-\mathrm{H}$ bending pada bidang aromatik), 1286,82 $\mathrm{cm}^{-1} \quad(\mathrm{C}-\mathrm{H}$ bending alkana/alifatik $), \quad 1593,2 \quad \mathrm{~cm}^{-1} \quad(\mathrm{C}=\mathrm{O}$ kemungkinan dari lakton, karbosil, anhidrat, $\mathrm{C}=\mathrm{C}$ aromatik), $2827,64 \mathrm{~cm}^{-1}, 2893.22 \mathrm{~cm}^{-1}$ (C-H alkana/alifatik), $3302,13 \mathrm{~cm}^{-1}$ (stretch OH ikatan hidrogen) (Silverstein, 1991). Dengan demikian, arang aktif yang berasal dari batang tanaman gumitir yang diaktivasi dengan natrium hidroksida pada konsentrasi 2,5\% memiliki gugus $\mathrm{C}-\mathrm{H}$ aromatik/alifatik, $\mathrm{C}=\mathrm{O}$, $\mathrm{C}=\mathrm{C}$ aromatik, dan $\mathrm{O}-\mathrm{H}$ ikatan hidrogen.

\section{SIMPULAN DAN SARAN}

\section{Simpulan}

Berdasarkan penelitian yang telah dilakukan maka diperoleh simpulan sebagai berikut:

1. Konsentrasi $\mathrm{NaOH}$ mempengaruhi beberapa karakteristik arang aktif yang dihasilkan dari limbah batang tanaman gumitir (Tagetes erecta). Aktivasi dengan $\mathrm{NaOH}$ dalam penelitian ini, secara umum menghasilkan arang aktif dengan karakteristik yang baik yang memenuhi standar mutu menurut SNI 06 - 3730 1995 tentang arang aktif teknis.

2. Konsentrasi $\mathrm{NaOH} 2,5 \%$ menghasilkan arang aktif dengan karakter terbaik, dengan kadar air sebesar $1,25 \pm 0,15 \%$, kadar zat mudah menguap sebesar $12,00 \pm 0 \%$, kadar

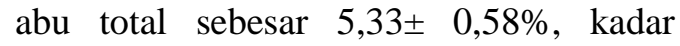
karbon sebesar $81,41 \%$, dan daya serap terhadap metilen biru sebesar 199,97 $\pm 0,03$ $\mathrm{mg} /$, daya serap terhadap $\mathrm{I}_{2}$ sebesar $728,09 \pm 1,27 \mathrm{mg} / \mathrm{g}$. Hasil analisis spektrofotometer FTIR menunjukkan arang aktif mengandung gugus $\mathrm{C}-\mathrm{H}$ alifatik, $\mathrm{C}=\mathrm{O}, \mathrm{C}=\mathrm{C}$ aromatik, $\mathrm{O}-\mathrm{H}$ ikatan hidrogen.

\section{Saran}

Saran yang dapat disampaikan adalah perlu dilakukan penelitian lebih lanjut mengenai kemampuan arang aktif dari batang tanaman gumitir (Tagetes erecta) yang diaktivasi dengan $\mathrm{NaOH}$ dalam aplikasinya sebagai adsorben logam berat atau senyawa organik dalam limbah cair ataupun melakukan aktivasi dan karakterisasi arang dengan menggunakan aktivator kimia yang lainnya .

\section{UCAPAN TERIMAKASIH}

Penulis menyampaikan rasa terima kasih yang sebesar-besarnya kepada Bapak Dr. Drs. Manuntun Manurung, MS., I Made Sutha Negara, S.Si., M.Si., dan Ibu Dr. Dra. Ni Made Suaniti, M.Si untuk semua masukannya sehingga laporan ini dapat terselesaikan dengan baik.

\section{DAFTAR PUSTAKA}

Cooney, D.O., 1980, Activated Charcoal, Antidotal, and Other Medical Uses, Marcel Dekker, New York.

Jankowska, H., Swiatkowski, A., dan Choma, J., 1991, Active Carbon, London, Horwood

Lersel, M. W. van, 2006, Respiratory $\mathrm{Q}_{10}$ of Marigold (Tagetes patula) in Response to Long-Term Temperature Differences and Its Realtionship to Growth and Maintenance Respiration, Physiologia Plantarum, 128, p: 289-301. 
Marsh, H. and F. R. Reinoso, 2006, Activated Carbon, Elsevier Ltd., 84 Theobald's Road, London, WCIZ 8RR, UK.

Sahara, E., W. D. Sulihingtyas, dan I P. A. S. Mahardika, 2017, Pembuatan dan Karakterisasi Arang Aktif dari Batang Tanaman Gumitir (Tagetes erecta) yang Diaktivasi dengan $\mathrm{H}_{3} \mathrm{PO}_{4}$, Jurnal Kimia, 11(1): 1-9

Siaka, I M., N. P. D. Febriyanti, E. Sahara, dan I M. S. Negara, 2016, Pembuatan dan Karakterisasi Arang Aktif dari Batang Tanaman Gumitir (Tagetes erecta) pada Berbagai Suhu dan Waktu Pirolisis, Cakra Kimia (Indonesian EJournal of Applied Chemistry), 4(2): 168-177.

Qin, C., Y. Chen, and J-m. Gaon, 2014,
Manufacture and Characterization of Activated Carbon from Marigold Straw (Tagetes erecta $L$ ) by $\mathrm{H}_{3} \mathrm{PO}_{4}$ Chemical Activation, Materials Letters, 135 p:123-12

Silverstein, R.M., G.C. Bassler, and T.C. Morrill, 1991, Spectrometric Identification of Organic Compounds, fifth edition, John Wiley and Sons, Singapore

SNI, 1995, SNI 06-3730-1995: Arang Aktif Teknis, Badan Standarisasi Nasional, Jakarta

Vasudevan, P., S. Kashyap, and S. Sharma, 1997, Tagetes: A Multi Purpose Plant, Biosresource Technology, 62, p: 29-35. 